\title{
Independent NF1 mutations underlie café-au-lait macule development in a woman with segmental NF1
}

Morgan E. Freret, PhD, Corina Anastasaki, PhD, and David H. Gutmann, MD, PhD

Neurol Genet 2018;4:e261. doi:10.1212/NXG.0000000000000261

\author{
Correspondence \\ Dr. Gutmann \\ gutmannd@wustl.edu
}

Segmental neurofibromatosis type 1 (NF1) is an under-recognized form of NF1 caused by postzygotic somatic loss-of-function $N F 1$ gene mutations that affect a subset of cells in the body. ${ }^{1}$ This is in contrast to classic or generalized NF1, in which a germline NF1 gene mutation affects all diploid cells in the body. In the segmental NF1 variant, individuals typically exhibit clinical features characteristic of generalized NF1, such as café-au-lait macules (CALMs), skinfold freckling, and neurofibromas, restricted to one segment of the body. For this reason, establishing the diagnosis can be challenging because the underlying NF1 gene mutation is often not detected in the blood. Underscoring the challenges of caring for individuals with this variant of NF1, we describe a woman with segmental NF1 referred to us at 22 years of age for evaluation.

The patient first came to medical attention at four months of age when her pediatrician noted that she had more than six CALMs localized to her right abdomen, back, and hip. Over the next five years, she developed additional hyperpigmented macules in this region, followed by freckling in the right inguinal region. Collectively, these findings met the criteria for a diagnosis of segmental NF1. On examination, the CALMs and skinfold freckling in the affected region did not cross either the anterior or posterior midlines, and there were no neurofibromas, other hyperpigmented lesions, or Lisch nodules detected. Because the affected body segment could potentially include her right ovary, at 28 years of age, she underwent genetic testing (direct Sanger sequencing, mixed ligation-dependent probe amplification, and interphase fluorescence in situ hybridization [FISH]), which failed to identify an NF1 gene mutation in her blood. She subsequently underwent biopsy of three of her CALMs (right lower back, hip, and abdomen), followed by primary culture of these skin melanocytes for genetic testing as above. ${ }^{2}$ As shown in the figure, sequencing and FISH revealed that all three CALM-derived melanocyte cultures shared a common 1.4 megabase deletion of the NF1 gene (type 1 total gene deletion [TGD]). Furthermore, in each of the three CALMs, a different second-hit mutation was identified that affected the remaining (non-deleted) NF1 gene copy.

This case report is instructive for several reasons. First, it underscores the utility of analyzing the affected tissues (e.g., melanocytes from multiple CALMs), rather than the blood, in establishing a diagnosis of segmental NF1. Although this patient met the diagnostic criteria for segmental NF1 on clinical grounds (regional distribution of CALMs and inguinal freckling), the genetic findings provide a reference for future prenatal genetic counseling and diagnostic testing. ${ }^{3}$ Second, genetic testing of affected tissue suggests that this patient sustained a total NF1 gene deletion during post-zygotic development and thus affected only a subset of her cells. Individuals with the generalized form of NF1 who harbor this type of mutation (type 1 TGD) frequently have a more severe phenotype, with greater numbers of neurofibromas and an increased risk of cancer, compared with individuals with generalized NF1 caused by other NF1 gene mutations. ${ }^{4}$ By contrast, this patient with segmental NF1 has no visible neurofibromas and is otherwise healthy, which is different from a previous report of several patients with segmental 
Figure Unique second neurofibromatosis type 1 (NF1) gene mutations in multiple café-au-lait macules (CALMs) from an individual with segmental NF1
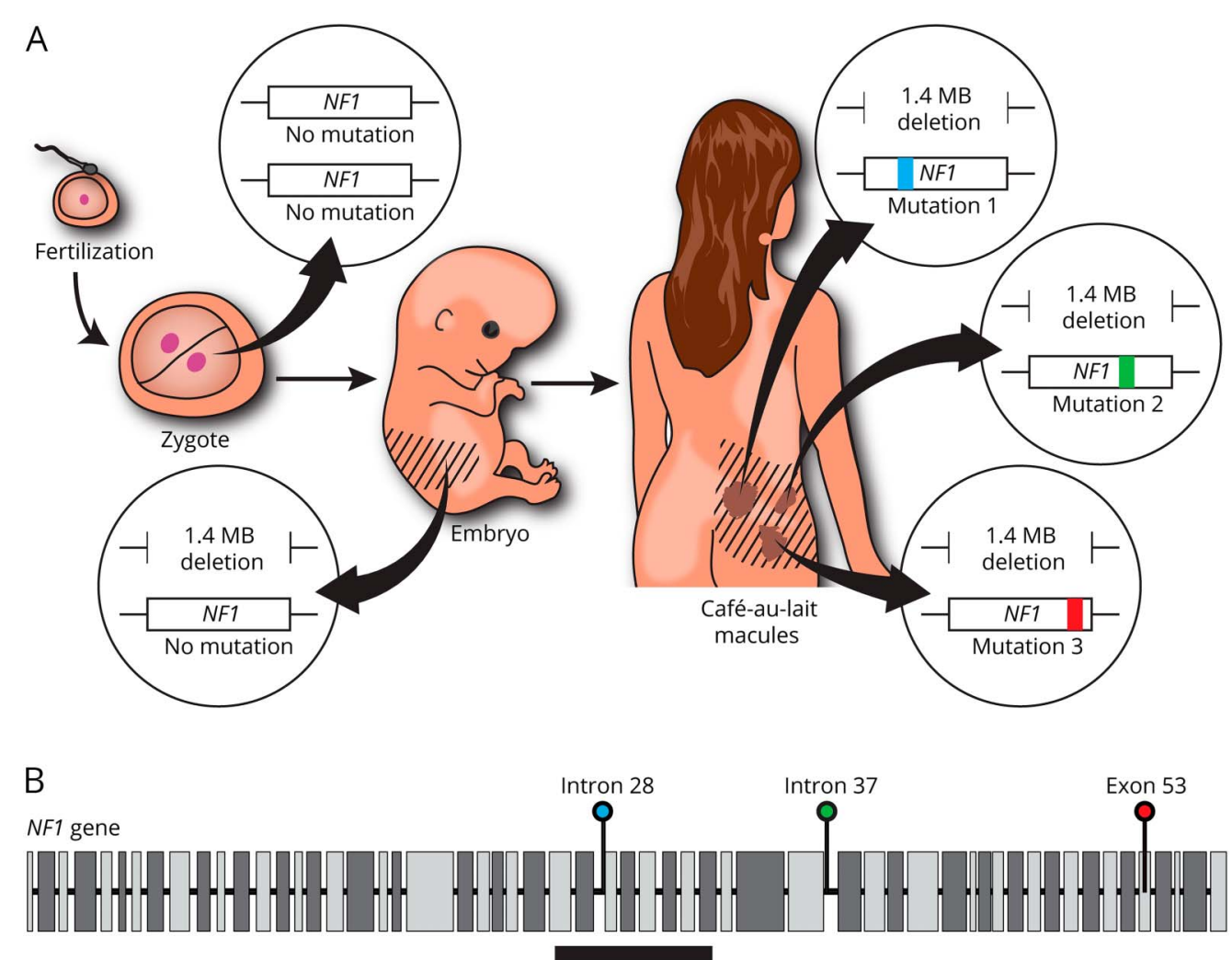

RAS GAP domain

\begin{tabular}{|c|c|c|c|c|}
\hline & NF1 gene mutation & Exon/intron & Mutation type & mRNA/protein change \\
\hline 1 & C.3871-2A>G & Intron 28 & Splice acceptor variant & Possible exon 29 skipping \\
\hline 2 & c.5546+5G $>$ A & Intron 37 & Splice donor variant & Possible exon 37 skipping \\
\hline 3 & c.7846C $>\mathrm{T}$ & Exon 53 & Nonsense mutation & Arg2616X \\
\hline
\end{tabular}

(A) Segmental or mosaic NF1 is caused by de novo NF1 gene mutations that occur during postzygotic development and affect only a subset of cells in the body. Genetic testing of melanocytes derived from three different CALMs in the patient's affected body segment (denoted by the diagonal stripes) revealed a common 1.4 megabase (MB) deletion, resulting in total loss of one copy of the NF1 gene, and three unique second-hit mutations affecting the remaining NF1 allele. The insets depict both NF1 gene copies in the indicated cell types. (B) Locations (colored pinheads) and predicted messenger RNA (mRNA) and protein changes resulting from the second NF1 gene mutations in melanocytes derived from three different CALMs. Two intronic mutations were located within splice sites, and one exonic mutation resulted in a premature stop codon (nonsense mutation). Short black boxes denote introns; tall gray boxes denote exons.

NF1 and type 1 TGDs. ${ }^{5}$ In that series, four of the five cases had either numerous dermal neurofibromas or a plexiform neurofibroma. The less severe phenotype in the current subject suggests that, compared with previously reported cases, (1) her total NF1 gene deletion may have arisen at a later developmental stage, (2) it is restricted to a different population of cells, or (3) modifier genes additionally influence clinical expression. Third, each of the CALMs in this patient contained melanocytes harboring a unique second NF1 gene mutation that presumably resulted in loss of or impaired function of the NF1-encoded protein (neurofibromin) in those cells. This finding is consistent with previous reports demonstrating biallelic NF1 gene inactivation in CALMs, ${ }^{6,7}$ similar to that observed in benign tumors from patients with NF1. ${ }^{2}$ The finding that the second-hit mutations were distinct in each CALM argues that each macule arose independently, similar to benign neoplasms (i.e., neurofibromas) that arise in this population of tumor-prone individuals.

\section{Author contributions}

M.E. Freret contributed to manuscript preparation and made the figure. C. Anastasaki contributed to manuscript preparation. D.H. Gutmann wrote the first draft of the manuscript.

\section{Study funding}

This work was supported by the NIH (1-R35-NS07211-01, D.H. Gutmann).

\section{Disclosure}

M.E. Freret and C. Anastasaki report no disclosures. D.H. Gutmann holds patents for the identification of the ND1 gene and $\mathrm{mTOR}$ regulator; has received research support from the US Army Department of Defense, the Giorgio Foundation, 
the Children's Tumor Foundation, and the Neurofibromatosis Acceleration Therapeutics Program; receives license fee payments for the TSC1 knockout mouse; and receives royalty payments for the NF1 gene patent. Full disclosure form information provided by the authors is available with the full text of this article at Neurology.org/NG.

Received March 20, 2018. Accepted in final form April 24, 2018.

\section{References}

1. Listernick R, Mancini AJ, Charrow J. Segmental neurofibromatosis in childhood. Am J Med Genet A 2003;121A:132-135.
2. Maertens O, De Schepper S, Vandesompele J, et al. Molecular dissection of isolated disease features in mosaic neurofibromatosis type 1. Am J Hum Genet 2007;81: 243-251.

3. Ko Y, Lee C, Lee H, Lee M, Lee JS. Clinical application of next-generation sequencing for the diagnosis of segmental neurofibromatosis. J Dermatol Sci 2017;88:370-372.

4. Kehrer-Sawatzki H, Mautner VF, Cooper DN. Emerging genotype-phenotype relationships in patients with large NF1 deletions. Hum Genet 2017;136:349-376.

5. Messiaen L, Vogt J, Bengesser K, et al. Mosaic type-1 NF1 microdeletions as a cause of both generalized and segmental neurofibromatosis type-1 (NF1). Hum Mutat 2011; 32:213-219.

6. Eisenbarth I, Assum G, Kaufmann D, Krone W. Evidence for the presence of the second allele of the neurofibromatosis type 1 gene in melanocytes derived from cafe au laitmacules of NF1 patients. Biochem Biophys Res Commun 1997;237:138-141.

7. De Schepper S, Maertens O, Callens T, Naeyaert JM, Lambert J, Messiaen L. Somatic mutation analysis in NF1 cafe au lait spots reveals two NF1 hits in the melanocytes. J Invest Dermatol 2008;128:1050-1053. 


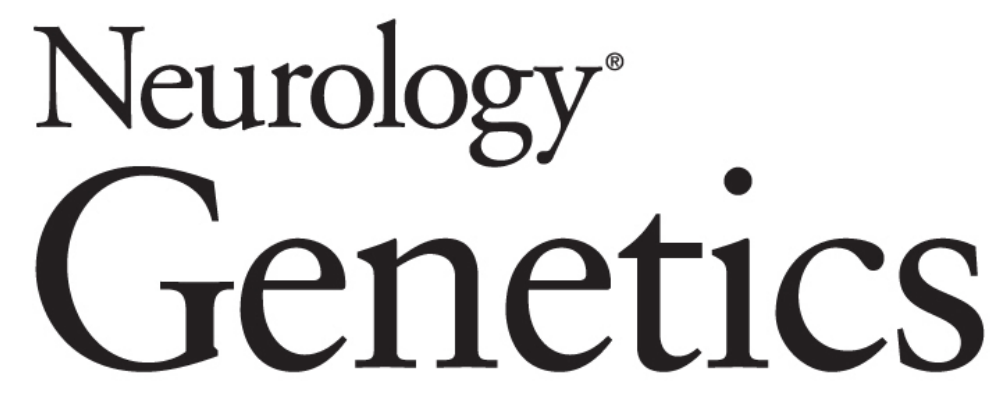

\section{Independent NF1 mutations underlie café-au-lait macule development in a woman with segmental NF1}

Morgan E. Freret, Corina Anastasaki and David H. Gutmann

Neurol Genet 2018;4;

DOI 10.1212/NXG.0000000000000261

This information is current as of July 23, 2018

\section{Updated Information \&} Services

References

Subspecialty Collections

Permissions \& Licensing

Reprints including high resolution figures, can be found at: http://ng.neurology.org/content/4/4/e261.full.html

This article cites 7 articles, 0 of which you can access for free at: http://ng.neurology.org/content/4/4/e261.full.html\#\#ref-list-1

This article, along with others on similar topics, appears in the following collection(s):

All Clinical Neurology

http://ng.neurology.org//cgi/collection/all_clinical_neurology All Genetics

http://ng.neurology.org//cgi/collection/all_genetics

Neurofibromatosis

http://ng.neurology.org//cgi/collection/neurofibromatosis

Information about reproducing this article in parts (figures,tables) or in its entirety can be found online at:

http://ng.neurology.org/misc/about.xhtml\#permissions

Information about ordering reprints can be found online: http://ng.neurology.org/misc/addir.xhtml\#reprintsus

Neurol Genet is an official journal of the American Academy of Neurology. Published since April 2015, it is an open-access, online-only, continuous publication journal. Copyright Copyright @ 2018 The Author(s). Published by Wolters Kluwer Health, Inc. on behalf of the American Academy of Neurology.. All rights reserved. Online ISSN: 2376-7839.

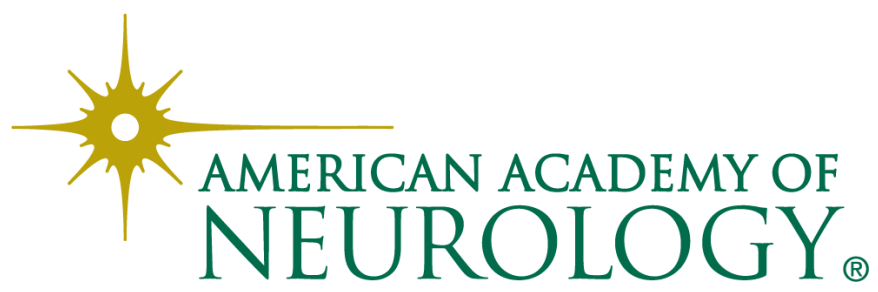

